UDC 661.888.1:621.793

\author{
J. C. Caicedo ${ }^{1, *}$, R. Gonzalez ${ }^{1}$, H. H. Caicedo ${ }^{2,3}$, \\ M. Gholipourmalekabadi ${ }^{4}$, C. Amaya ${ }^{5}$ \\ ${ }^{1}$ Tribology, Powder Metallurgy and Processing of Solid Recycling \\ Research Group, Universidad del Valle, Cali, Colombia \\ ${ }^{2}$ Janssen BioTherapeutics, Janssen Research \& Development, LLC, \\ Pharmaceutical Companies of Johnson \& Johnson, Spring House, \\ PA, USA \\ ${ }^{3}$ National Biotechnology and Pharmaceutical Association, \\ Chicago, USA \\ ${ }^{4}$ Biotechnology Department, School of Medicine, Shahid Beheshti \\ University of Medical Sciences, Tehran, Iran \\ ${ }^{5}$ Grupo de Investigación en Materiales ASTIN SENA, Cali, Colombia \\ *jcaicedoangulo1@gmail.com
}

\title{
Mechanical and tribological properties of V-C-N coatings as a function of applied bias voltage
}

The aim of this work is to determine the mechanical and tribological behavior of $\mathrm{V}-\mathrm{C}-\mathrm{N}$ coatings deposited on industrial steel substrates (AISI 8620) by using carbon-nitride coatings as a protective materials. The coatings were deposited on silicon (100) and steel substrates via magnetron sputtering and by varying the applied bias voltage. The $V-C-N$ coatings were characterized by $X$-ray diffraction (XRD), exhibiting the crystallography orientations (111) FCC for $V-C-N$ conjugated by VC (111) and VN (111) phases and (200) FCC for V-C-N conjugated by VC (200) and VN (200) phases. X-ray photoelectron spectroscopy (XPS) was used to determine the chemical composition of metallic carbon-nitride materials. Atomic force microcopy (AFM) was used for determination of the change in grain size and roughness with deposition parameters. By using nanoindentation, pin-on-disk, and scratch test curves, it was possible to estimate the hardness, friction and critical load of $\mathrm{V}-\mathrm{C}-\mathrm{N}$ surface material. Scanning electron microscopy (SEM) was performed to analyze morphological surfaces changes. Mechanical and tribological behavior in VCN/steel ${ }_{\text {[8620] }}$ system, as a function of a bias voltage deposition, showed an increase of $58 \%$ in the hardness, and reduction of $39 \%$ in the friction coefficient, indicating thus that the $\mathrm{V}-\mathrm{C}-\mathrm{N}$ coatings may be a promising material for industrial applications.

Keywords: surfaces, crystal growth, physical vapor deposition, mechanical testing, tribology and wear.

\section{INTRODUCTION}

Mechanical and tribologoical properties of hard coatings have been extensively studied and contributed to the improvement of the surface properties of a myriad of industrial devices such as cutting tools and injection molds for polymeric materials [1]. In this regard, the literature reports on different systems and heterostructures based on nitride, carbide, and carbon nitride such as $\mathrm{ZrCN}$ [1], TiCN [2], NbCN [3], and CrN/AlN [4], which exhibits high corrosion resistance and acceptable tribological properties. Other transition metals such as vanadium 
(V) have been used as binary coatings (e.g., VC and VN), thus showing relevant mechanical and electrochemical properties [5, 7]. Accordingly, in the current literature it is possible to observe novel reports on coatings based on conjugate complexes for $\mathrm{V}-\mathrm{C}-\mathrm{N}$ from VC and VN materials [8]. Moreover, it has become established that the carbon nitride with transition metals has very promising physical characteristics due to high chemical and physical stabilities, which allow many applications under several mechanical conditions. Interestingly, G. Kamath et al. [9] reported the microstructure-property relationship of reactively magnetron sputtered $\mathrm{VC}_{x} \mathrm{~N}_{y}$ films. Nevertheless, the literature still presents a few research examples focused on analysis of mechanical and tribological properties for VCN system as a function of applied negative bias voltage, which is critical in the understanding of carbon-nitride system for industrial application under aggressive environments. Furthermore, changes of physical properties (hardness, elastic modulus, friction coefficient and critical load) on steel coated with VCN have not yet been thoroughly studied. Often, a decrease of functional performance of this material is observed in devices with industrial application (e.g., cutting tools, injection molds, and surgical devices). The aim of this work is to study the effect of negative bias voltage on the structural and mechanical properties of $\mathrm{V}-\mathrm{C}-\mathrm{N}$ coatings deposited on commercial AISI 8620 steel with different bias voltages from 0 to $-100 \mathrm{~V}$ (with $2 \mu \mathrm{m}$ of thickness) for possible metalworking applications.

\section{EXPERIMENTAL DETAILS}

V-C-N coatings were grown on silicon (100) and AISI 8620 steel substrates by using a multitarget magnetron reactive sputtering technique, with an r.f. source $(13.56 \mathrm{MHz})$ and two stoichiometric vanadium (V) and graphite (C) targets of $99.9 \%$ purity for both targets. The deposition parameters for obtaining highquality coatings were sputtering power of $450 \mathrm{~W}$ for $\mathrm{V}$ and $400 \mathrm{~W}$ for the $\mathrm{C}$ target; substrate temperature of $300{ }^{\circ} \mathrm{C}$; under circular rotation substrate with 60 RPM to facilitate the formation of the stoichiometric coating; the sputtering gas was a mixture of $\mathrm{Ar} 92.5 \%$ and $\mathrm{N}_{2} 7.5 \%$ with a total working pressure of $6 \cdot 10^{-3}$ mbar, under argon and nitrogen gas flow of 50 and $3.75 \mathrm{sccm}$, respectively. An unbalanced r.f. bias voltage was applied, which generates a negative signal of $0,-40,-70$ and $100 \mathrm{~V}$ to systematically study its effect on coating electrochemical properties. The total thickness of all the coatings was kept constant around $2 \mu \mathrm{m}$. The crystallographic structure was analyzed via X-ray diffraction (XRD), with a Bruker D8 Advance diffractometer with $\mathrm{Cu}$ cathode (CuKa radiation $\lambda=1.5405 \AA$ ) and scintillation detector using a $0-20$ setting and performing a sweep from $20^{\circ}$ to $80^{\circ}$ with a pitch of 0.01 degrees and a step time of $2 \mathrm{~s}$.

The surface analysis for all coatings was determined by using a scanning electron microscopy Philips XL 30 FEG. The chemical composition of the coatings was determined via X-ray spectroscopy Photoelectron (XPS). Thus, the XPS experiments were performed in a SPECS Sage HR 100 spectrometer with a nonmonochromatic X-ray source (aluminum $\mathrm{K \alpha}$ line of $1486.6 \mathrm{eV}$ energy and a power applied of $300 \mathrm{~W}$ and calibrated using the $3 \mathrm{~d} 5 / 2$ line of $\mathrm{Ag}$ with a full width at half maximum (FWHM) of $1.1 \mathrm{eV}$ ). The selected resolution for the spectra was $30 \mathrm{eV}$ of Pass Energy and $0.5 \mathrm{eV} / \mathrm{step}$ for the general survey spectra and $10 \mathrm{eV}$ of Pass Energy and $0.15 \mathrm{eV} / \mathrm{step}$ for the detailed spectra of the different elements. All measurements were made in an ultra-high vacuum (UHV) chamber at a pressure around $5 \cdot 10^{-8}$ mbar. Samples were etched for 5 min with an $\mathrm{Ar}^{+}$ion beam with energy of $3 \mathrm{keV}$. Moreover, C1s spectra were fitted with software CasaXPS V2.3.15 using Gaussian Lorentzian functions (after a Shirley background 
correction), where the FWHM of all the peaks were constrained while the peak positions and areas were set free. The thickness for ternary coatings was around of $2 \pm 0.1 \mu \mathrm{m}$, and determined by means of a (Dektak 3030) Profilometer. Grain size and roughness was determined via atomic force microscopy (AFM-Asylum Research MFP-3D ${ }^{\circledR}$ ) and calculated by a Scanning Probe Image Processor (SPIP $\left.{ }^{\circledR}\right)$. In this work, SPIP ${ }^{\circledR}$ was used in the grain size analysis for a quantitative study of the grains and particles, and in the roughness analysis for an advanced measurement of the surface roughness. Hardness and elastic modulus measurements were performed by using a nanoindenter (UBI1-Hysitron) under load and unload mode with a matrix measurements of 25 points and maximum load of $8 \mathrm{mN}$. Moreover, tribological characterization was performed by means of Microtest, MT 400-98 tribometer, using a 6-mm diameter 100Cr6 steel ball like pattern slide. The applied load was $0.5 \mathrm{~N}$ with a total running length of $400 \mathrm{~m}$. Adherence of the layers was studied by using a Scratch Test Microtest MTR2 system. The parameters were a $6 \mathrm{~mm}$ scratch length and a raising load of 0-60 N.

\section{RESULTS AND DISCUSSION}

\section{$\mathrm{X}$-ray diffraction analysis}

Figure 1 shows the XRD patterns of the $\mathrm{V}-\mathrm{C}-\mathrm{N}$ coatings deposited on $\mathrm{Si}(100)$ for different r.f. negative bias voltages from 0 to $-100 \mathrm{~V}$. From that data, it is possible to infer that the coatings have a cubic structure based on complex conjugate with two substructures of vanadium carbide (VC) and vanadium nitride (VN). Therefore, the strongest peaks correspond to the V-C-N (111) and (200) planes, indicating a light textured growth along these orientations. The other weak peaks correspond to diffractions from V-C-N (220) planes of the fcc structure. With regard to the lattice parameter, it was obtained the value of $a_{0}( \pm 0.0001 \mathrm{~nm})$ for $\mathrm{V}-\mathrm{C}-\mathrm{N}$ coatings, where the Nelson-Riley function was employed in the refinement procedure (table). The presence of the $\mathrm{V}-\mathrm{C}-\mathrm{N}$ (111) obtained is associated to a substitution mechanism, where $\mathrm{C}$ atoms replace $\mathrm{N}$ atoms, resulting in a $\mathrm{V}$ ordered $\mathrm{C}-\mathrm{N}$ disordered fcc NaCl-type structure in which Ti placed the Wyckoff site $4 a$, while $\mathrm{C}$ and $\mathrm{N}$ atoms occupied randomly the Wyckoff site $4 b$ [9]. This means that the nitrogen gas flow rate influences directly the structure of $\mathrm{VC}_{1-x} \mathrm{~N}_{x}$ coatings. When the nitrogen gas flow rate is around $16 \mathrm{sccm}$ and r.f. negative bias voltages from 0 to $-100 \mathrm{~V}$ are used, $\mathrm{V}$ access to the deposition surface is facilitated; hence, the fcc structure is determined by a partially ordered structure with $\mathrm{V}$ atoms, creating vacancies in nonmetallic sublattices [9, 10]. On the other
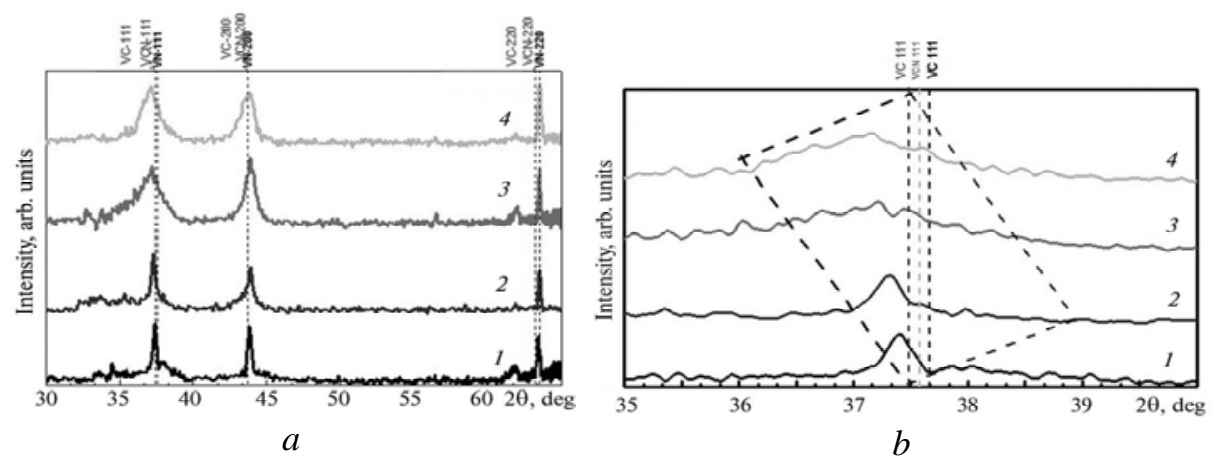

Fig. 1. XRD patterns: V-C-N coatings grown with different r.f. negative bias voltages (0 (1), -40 (2), -70 (3), -100 (4) V) (a) and maximum peak with shift toward low angles in relationship to the increase of applied r.f. negative bias voltage $(b)$; dash lines indicate the position of the peaks obtained from JCPDF files ((VN) JCPDF 00-035-0768 and (VC) JCDDF 01-073-0476). 
hand, it was observed that the $\mathrm{V}-\mathrm{C}-\mathrm{N}$ (111) peak position suffers a great deviation from bulk value for (VC and $\mathrm{VN}$ ) materials, indicating thus a possible stress evolution of $\mathrm{V}-\mathrm{C}-\mathrm{N}$ single layers with the applied r.f. negative bias voltage (see Fig. $1, b)$. The quasi-relaxed position observed for a lower bias voltage was progressively shifted to higher compressive stress values as the bias is increased until $-100 \mathrm{~V}$, therefore, this compressive effect is reached due to impact $\mathrm{Ar}^{+}$ mechanism actuating onto $\mathrm{V}-\mathrm{C}-\mathrm{N}$ coatings. For the higher negative bias voltage $(-100 \mathrm{~V})$, an abrupt change in $\mathrm{V}-\mathrm{C}-\mathrm{N}$ (111) peak position was observed, presenting a stress increasing due to the movement of this peak toward higher angles compared to other single layer. The stress changes in V-C-N (111) peak position come together with a low symmetric broadening and a decreasing in its intensity.

Lattice parameter and stoichiometric relationship determined by XPS of $\mathrm{V}-\mathrm{C}_{1-x} \mathrm{~N}_{x}$ coatings as a function of the negative bias voltage

\begin{tabular}{c|c|c|c}
\hline Negative bias voltage, $\mathrm{V}$ & $\mathrm{V}-\mathrm{C}_{1-x} \mathrm{~N}_{\times}$ & $\begin{array}{c}\mathrm{a}_{0}, \mathrm{~nm} \\
\mathrm{fcc}(111)\end{array}$ & $\mathrm{V} /(\mathrm{C}+\mathrm{N})$ \\
\hline 0 & $\mathrm{~V}_{55} \mathrm{C}_{27} \mathrm{~N}_{18}$ & 0.4161 & 1.20 \\
-40 & $\mathrm{~V}_{59} \mathrm{C}_{25} \mathrm{~N}_{16}$ & 0.4168 & 1.40 \\
-70 & $\mathrm{~V}_{54} \mathrm{C}_{28} \mathrm{~N}_{18}$ & 0.4180 & 1.17 \\
-100 & $\mathrm{~V}_{55} \mathrm{C}_{28} \mathrm{~N}_{17}$ & 0.4187 & 1.22 \\
\hline
\end{tabular}

\section{XPS analysis of VCN coating}

The XPS survey spectra for all V-C-N single layers as function of a negative bias voltage from 0 to $-100 \mathrm{~V}$ are shown in Fig. 2. According to the XPS literature regarding $\mathrm{VC}_{1-x} \mathrm{~N}_{x}$ coatings materials [9, 11], the concentration measurements and identification of the specific bonding configurations for the $\mathrm{VC}_{1-\chi} \mathrm{N}_{x}$ layers are more reliable when XPS analysis is used. Hence, the composition of the $\mathrm{VC}_{1-\gamma} \mathrm{N}_{x}$ coating is slightly over stoichiometric (see table), which is attributed to the huge number of nitrogen vacancies that can be accommodated in the face centered cubic structure of $\mathrm{VC}_{1-\chi} \mathrm{N}_{x}$ analyzed by XRD (see Fig. 1) [11]. So, the electronic spectra carry information of the chemical composition and bonding characteristics of the $\mathrm{VC}_{1-x} \mathrm{~N}_{x}$ coatings generating thus an increase in the reliability of the results. Finally, the carbon (C) signal presence can be associated to a few surface contaminations. In this sense, the binding energies' identification was realized in agreement with NIST X-ray photoelectron spectroscopy Database 20, Version 3.5. So, the integral V2p, C1s, and N1s, spectra corrected by relevant sensitive factors can evaluate the concentrations of $\mathrm{V}$ and $\mathrm{N}$ elements of $\mathrm{VC}_{1-\chi} \mathrm{N}_{x}$ coatings. The corresponding integral of the deconvoluted peaks can also be used to estimate the bond contents, which are described by the following equation (1) [12]:

$$
C_{i}=\frac{\sum\left(\frac{A_{i}}{S_{i}}\right)}{\sum\left(\frac{A_{j}}{S_{j}}\right)},
$$

where $S$ is the sensitivity factor, $A$ is the integral of deconvoluted peaks, and $C_{i}$ is the atomic content. The numerator is the sum of the integral of one sort of bond; the 
denominator is the sum of the integral of all types of bonds decomposed from the whole peak of V2p, C1s and N1s, spectra in the sample. In the chemical composition of the coating (see table), the prevalence of ternary carbon nitride $\left(\mathrm{VC}_{1-\chi} \mathrm{N}_{x}\right)$, such as it is shown in the $\mathrm{X}$-ray diffraction pattern, is evident (see Fig. 1).

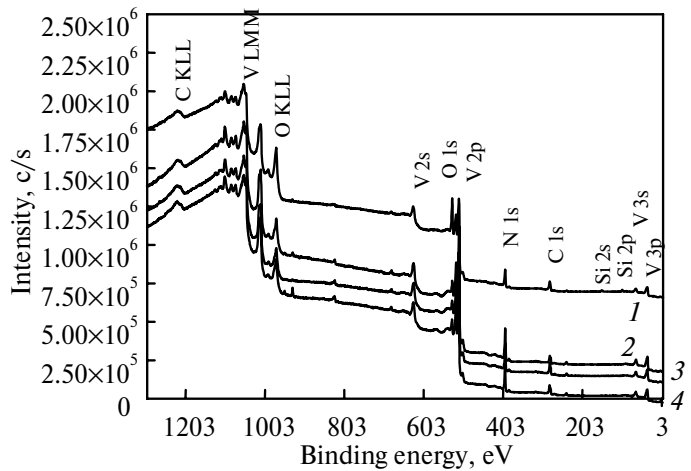

Fig. 2. XPS survey spectrum for $\mathrm{VC}_{1-x} \mathrm{~N}_{x}$ coatings deposited on Si substrate with the r.f. negative bias voltage from 0 to $-100 \mathrm{~V}$ : 0 (1), -40 (2), -70 (3), -100 (4) V.

Regarding the $\mathrm{VC}_{1-x} \mathrm{~N}_{x}$ coating deposited with the applied negative bias voltage of $40 \mathrm{~V}$, Fig. 3 shows the peaks with highest intensity corresponding to $\mathrm{V}-\mathrm{N}(514.4 \mathrm{eV})$ and V-C (513.3 eV) bounds at V2p signal, C-C $(285.0 \mathrm{eV})$ bounds at C1s signal, and $\mathrm{N}-\mathrm{V}(397.4 \mathrm{eV})$ bounds at N1s signal evidencing the formations of metal-nitride and metal-carbide bounds. [12-14]. In this sense, for V2p signal (see Fig. 3, a), it was found the energy bindings for $\mathrm{V}^{2} \mathrm{p}_{1 / 2}$ signal with $\mathrm{V}-\mathrm{O}(523.6 \mathrm{eV}), \mathrm{V}-\mathrm{N}(522.8 \mathrm{eV})$ bounds, moreover, for $\mathrm{V}_{2} \mathrm{p}_{3 / 2}$ signal was found $\mathrm{O}-\mathrm{V}-\mathrm{O}(516.4 \mathrm{eV})$ bound [15].

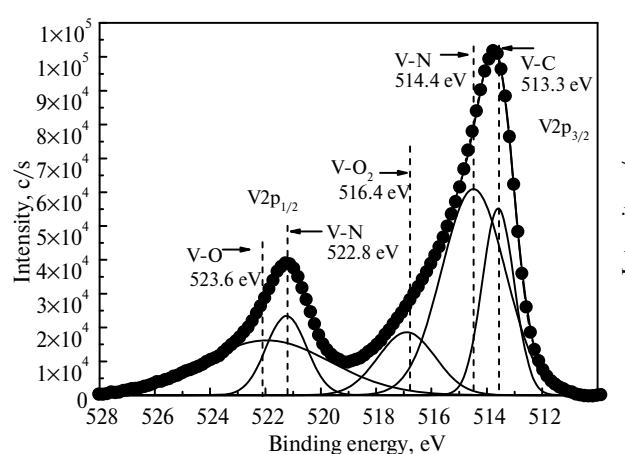

$a$
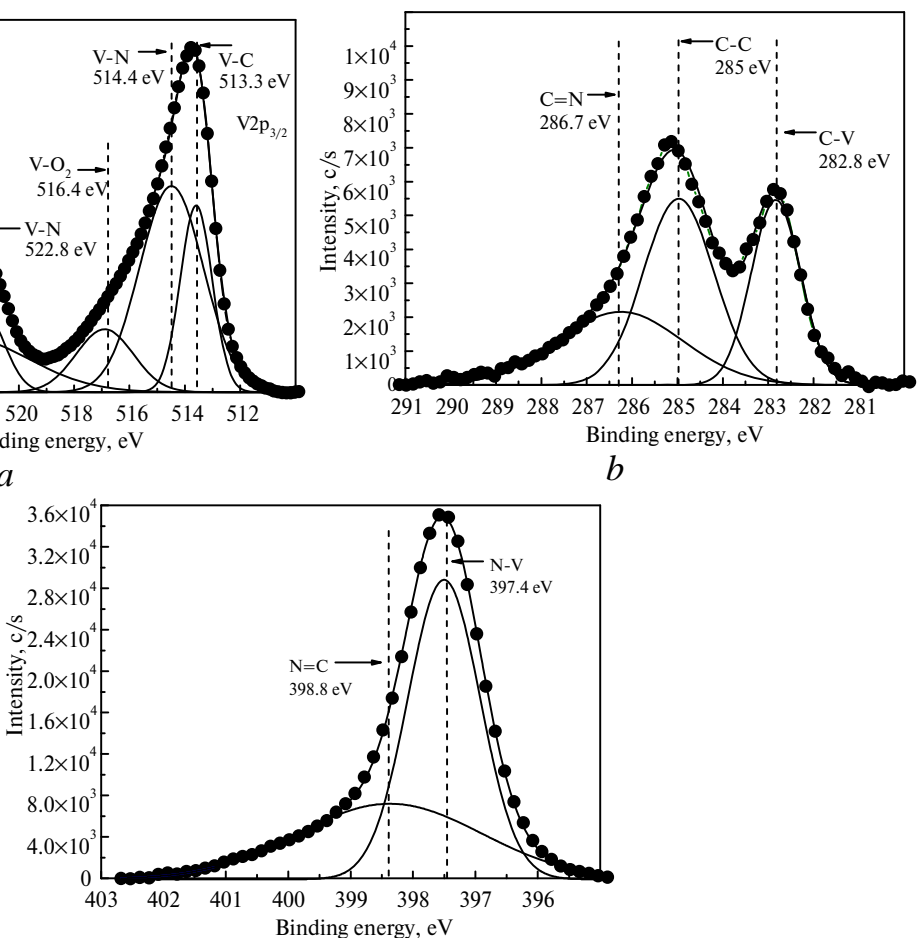

Fig. 3. High-resolution spectrum for V-C-N coatings: V2p (a), C1s (b), N1s signals (c). 
For C1s signal (see Fig. 3, b), it was found the energy bindings of $286.7 \mathrm{eV}$ for $\mathrm{C}=\mathrm{N}$ bounds, $285.0 \mathrm{eV}$ for $\mathrm{C}-\mathrm{C}$ bonds and $282.8 \mathrm{eV}$ for bounds $\mathrm{C}-\mathrm{V}$ associated to chemical interaction in $\mathrm{VC}_{1-x} \mathrm{~N}_{x}$ molecule [16]. Moreover, the Fig. 3, $c$ exhibits the energy bindings for $\mathrm{N}=\mathrm{C}$ with $398.8 \mathrm{eV}$, and $\mathrm{N}-\mathrm{V}$ with $397.4 \mathrm{eV}$, showing thus, the organic and metallic principal bounds [17]. The change of binding energy compared to $\mathrm{VC}_{1-x} \mathrm{~N}_{x}$ single layer materials verifies the formation of $\mathrm{V}-\mathrm{C}-\mathrm{N}$ layer; therefore, calculating the peak area yields an atomic ratio of $\mathrm{V}_{59} \mathrm{C}_{25} \mathrm{~N}_{16}$, similar to others reports in the literature [18]. Accordingly, the last stoichiometric relation corresponds to chemical bounds, which are contained in fcc structure present in $\mathrm{VC}_{1-x} \mathrm{~N}_{X}$ material (XRD results (see Fig. 1)).

\section{Surface analysis by AFM}

Surface morphology of ternary materials in relation to the increasing negative bias voltage on V-C-N coatings deposited onto Si (100), was studied. Figure 4 shows AFM images for single layer coatings with statistical distribution of grain size $5 \mu \mathrm{m} \times 5 \mu \mathrm{m}$ for the bias voltage $-0(a),-40(b),-70(c),-100(d) \mathrm{V}$.

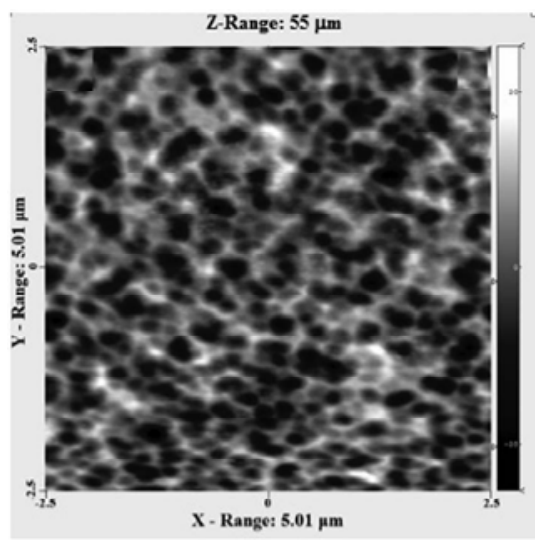

$a$

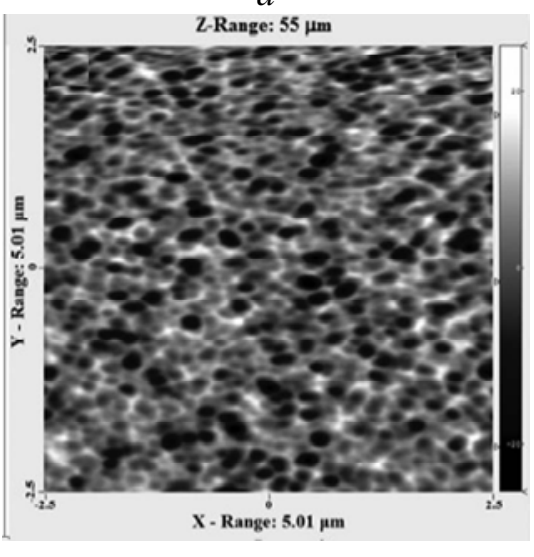

C

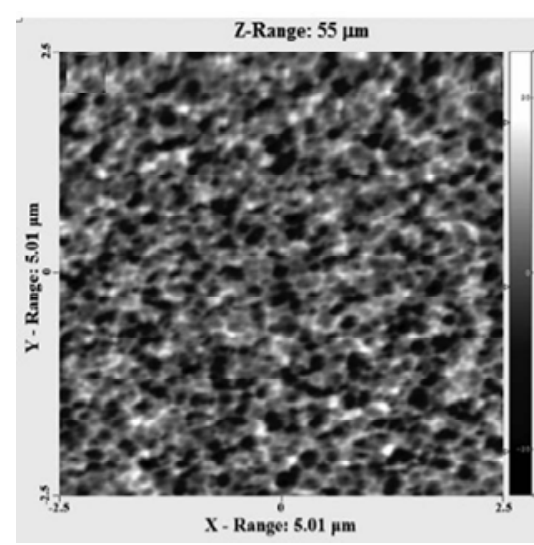

b

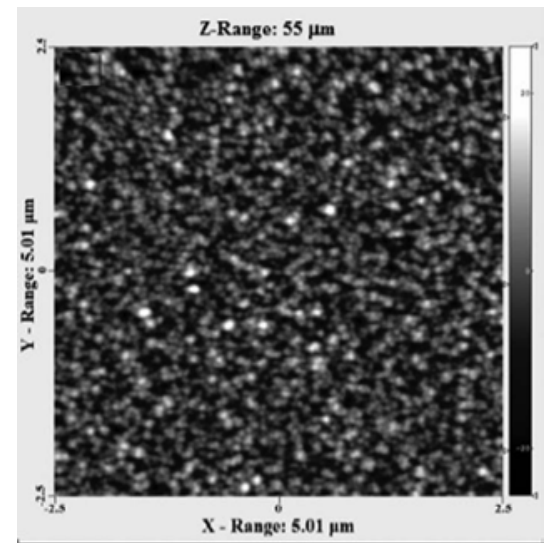

$d$

Fig. 4. AFM images for $\mathrm{V}-\mathrm{C}-\mathrm{N}$ coatings deposited at the negative bias voltage of $0(a),-40(b)$, $-70(c),-100(d) \mathrm{V}$.

Figure 5 shows AFM results where each data point in the graphs represents an average over 4 AFM images for each sample. It is also possible to compare the grain size (see Fig. 5, a) and roughness (see Fig. 5, b) values for $\mathrm{V}-\mathrm{C}-\mathrm{N}$ single layers; therefore, in this study it was found a decreasing trend for grain size and 
roughness when the bias voltage is increased. Moreover, this study found that the lowest value for the grain size is associated with the layers deposited with $-100 \mathrm{~V}$ (see Fig. 5, b), determining thus a reduction in the grain size of $39.5 \%$ for the $\mathrm{V}-$ $\mathrm{C}-\mathrm{N}$ layer, in relation to grain sizes obtained for the deposited layers to $0 \mathrm{~V}$, respectively. Furthermore, it is possible to observe a reduction in the grain size of $43 \%$ for the ternary coatings, in relation to grain sizes obtained for the deposited layers at $0 \mathrm{~V}$, respectively. This is relevant, since the surface morphology plays an important role in the mechanical and tribological properties.

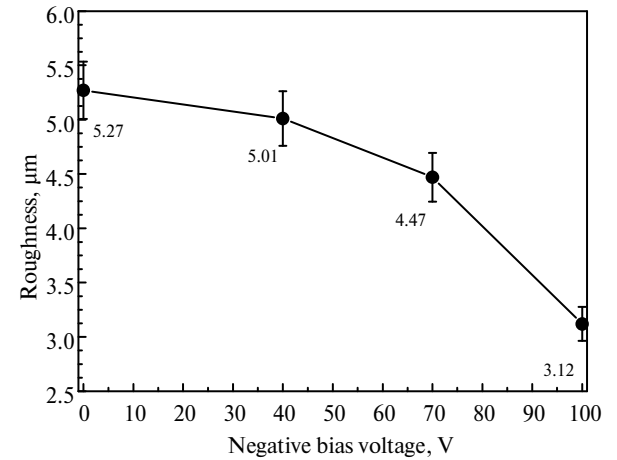

$a$

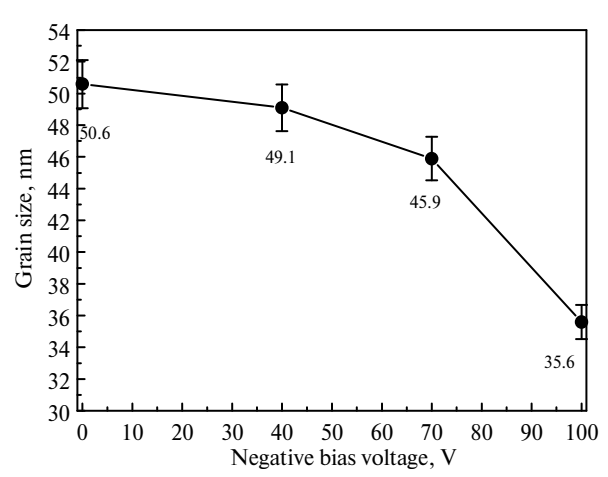

$b$

Fig. 5. Morphological analysis obtained from AFM results: roughness $(a)$ and grain size $(b)$ as a function of applied negative bias voltages from 0 to $-100 \mathrm{~V}$. Corresponding error bars were obtained by the standard deviation of the values using the statistical data processor for images (SPIP $\left.{ }^{\circledR}\right)$.

\section{Mechanical properties}

Load-displacement indentation curves of $\mathrm{V}-\mathrm{C}-\mathrm{N}$ layers using the standard Berkovich indenter and indentation matrix image via AFM are shown in Figs. 6, $a$ and $b$. The values of elasticity modulus, $E$, and hardness, $H$, were obtained by using Oliver and Pharr's method in multilayers deposited on AISI 4140 steel substrates $[4,19]$. Hardness values of both, $\mathrm{V}-\mathrm{C}-\mathrm{N}$ coatings and the ternary coating measured by nanoindentation as a function of applied negative bias voltage, are presented in Fig. 7, $a$ and Fig. 8, $a$, respectively.

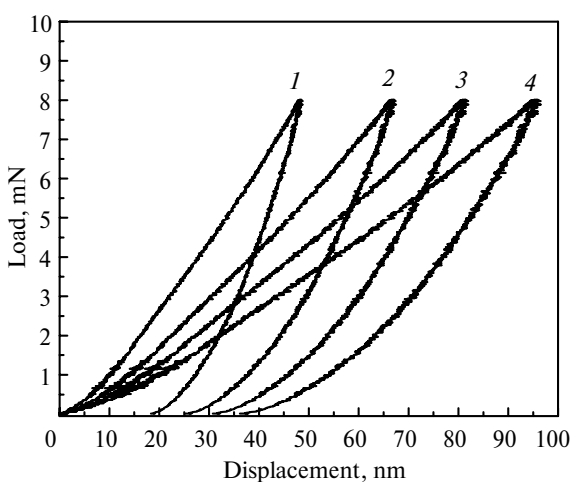

$a$

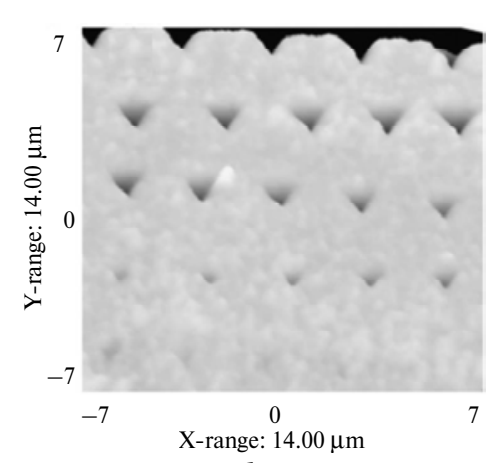

$b$

Fig. 6. Nanoindentation measurements: load-displacement indentation curves of VCN system (-100 (1), -70 (2), -40 (3), 0 (4) V) (a) and AFM image of indentation matrix for ternary coatings deposited with a negative bias voltage of $-40 \mathrm{~V}(b)$. 

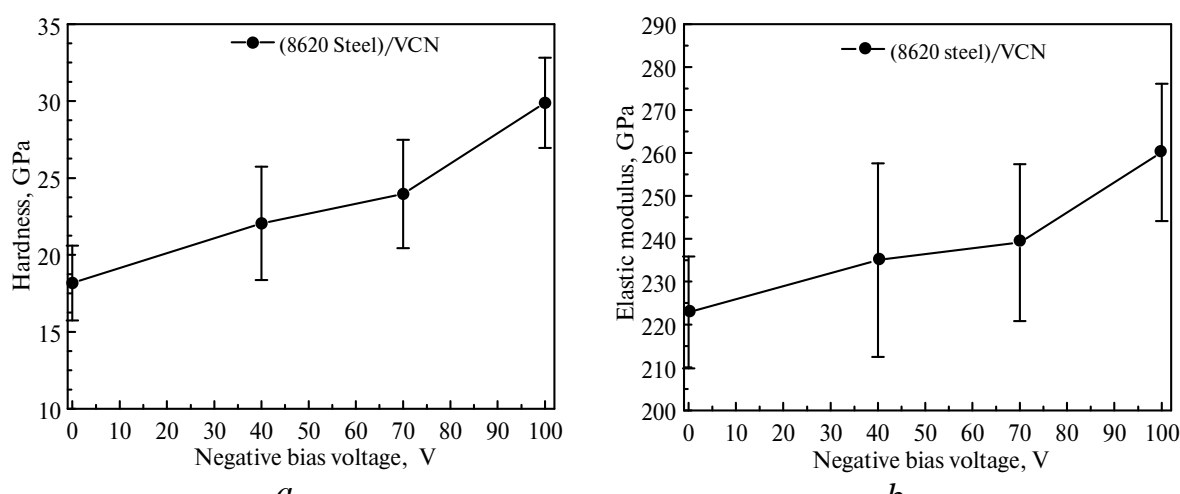

$a$

Fig. 7. Mechanical properties for $\mathrm{V}-\mathrm{C}-\mathrm{N}$ coatings as a function of applied negative bias voltage: hardness as a function of $n(a)$ and elastic modulus $(b)$.

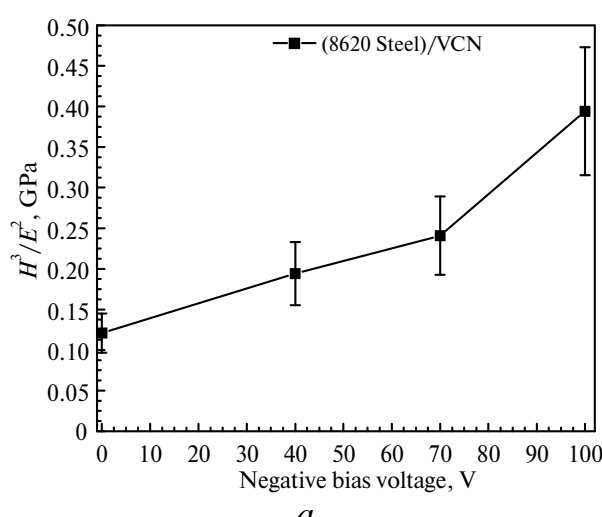

$a$

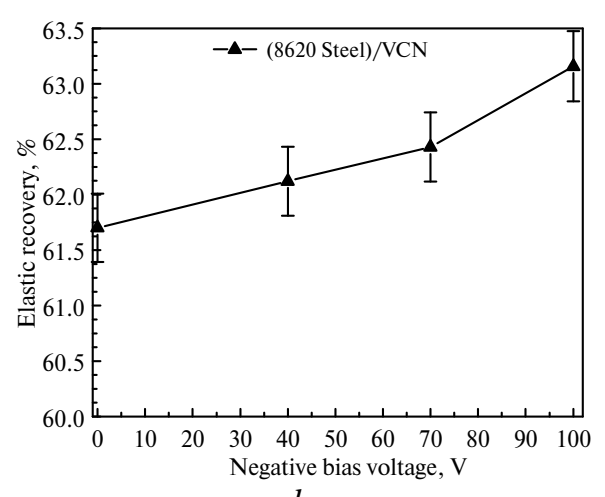

$b$

Fig. 8. Elasto-plastic properties with plastic deformation for $\mathrm{V}-\mathrm{C}-\mathrm{N}$ single layer coatings growth with the negative bias voltage form 0 to $-100 \mathrm{~V}$ : plastic deformation resistance (a) and elastic recovery $(b)$.

Elastic modulus values of ternary layers are also presented in Fig. 7, $b$, which show relevant differences in their values in relation to the different applied negative bias. Moreover, the hardness and elastic modulus in these single layer coatings varied from 18 to $30 \mathrm{GPa}$ and from 223 to $260 \mathrm{GPa}$, respectively. The highest hardness of the $\mathrm{V}-\mathrm{C}-\mathrm{N}$ coatings corresponding to $30 \mathrm{GPa}$, was obtained by the highest negative bias $(-100 \mathrm{~V})$, therefore, was increase a $40 \%$ of hardness in relation to coating growth with $0 \mathrm{~V}$ voltage. This increase in mechanical properties is related to the remarked densifying effect that is present when the bias voltage is applied, inducing the impact of $\mathrm{Ar}^{+}$ions on coating surface, thus creating greater momentum transfer and generating an increase of residual stress in the $\mathrm{V}-\mathrm{C}-\mathrm{N}$ coating showing within the (111) crystallography direction study by XRD results (see Fig. 1,b). The enactment in the mechanical properties can be associated with a hardness improvement by using coating with lower grain size, as observed from AFM images (see Fig. 4) [4, 20, 21].

The high interface density of ternary coatings contributes to impeding dislocation motion and the dislocation glide across the grain boundaries, which would require a critical yield stress being related to the difference in the elastic shear modulus of the single layer deposited without a bias voltage [22, 23]. The Hall-Petch effect is routinely used to explain material hardening. Therefore, when metal-ceramic materials such hard, $\mathrm{V}-\mathrm{C}-\mathrm{N}$ coatings with grain size higher than 
$5.2 \mathrm{~nm}$ are obtained, it is possible to apply the Hall-Petch effect to explain the hardening, because the current $\mathrm{V}-\mathrm{C}-\mathrm{N}$ coatings with lower grain size are within nanoscale regimen (AFM results, see Figs. 4, 5), and thus the dislocations should not occur in nanoscale structures below a certain value of grain sizes $(5.2 \mathrm{~nm})$ [19]. In this sense, Fig. 7, $a$ shows that the hardness for single layer coatings is related to the bias voltage for the effect of the grain size reduction [21-23].

Additionally, it was possible to analyze the influence of the bias voltage on coating hardness, as hardness values increase with the increases of applied voltage. This result can be explained by correlating with the results obtained by AFM where the increase of the applied voltage decreases the grain size, which increases grain boundaries and results in an increase in coating hardness due to the Hall-Petch effect as shown by the following equation [24]:

$$
H=H_{0}+k D^{-1 / 2} \text {, }
$$

where $H$ is the hardness of the polycrystalline material with grain size $D, H_{0}$ is the hardness of the same material with a larger grain size, and $k$ is a constant measure of relative hardening with the contribution of grain boundaries. The increase of coatings hardness is attributed to the increase of the bias voltage associated with increase sputtering of $\mathrm{Ar}^{+}$atoms causing a higher density and a reduction in grain size. The grain boundaries act as barriers to the movement of dislocations in the $\mathrm{V}-\mathrm{C}-\mathrm{N}$ material, thus a dislocation is difficult to move from one grain to another across borders due to a relative disorder, in which the atoms are in that area, causing the material with small grains to have higher hardness. These results indicate that the mechanical properties of hardness and elastic modulus (Young's modulus (Er)) are highly dependent on a bias voltage [25].

On the other hand, plastic deformation resistance $\left(H^{3} / E^{2}\right)[26]$ and elastic recovery $(R)$ in the carbon nitride coatings are shown in Fig. 9. Elastic recovery for all $\mathrm{V}-\mathrm{C}-\mathrm{N}$ coatings was calculated by using the following equation:

$$
R=\frac{\delta_{\max }-\delta_{p}}{\delta_{\max }},
$$

where $\delta_{\max }$ and $\delta_{p}$ are the maximum and residual or plastic displacement, respectively [27, 28]. Data for the equation were taken from the load-penetration depth curves of indentations for each coating, according to Fig. 6, $a$. From Fig. 8, the carbon nitride coatings increased the plastic deformation resistance and elastic recovery with respect to the applied negative bias voltage. The maximum value was reached for $\mathrm{V}-\mathrm{C}-\mathrm{N}$ system deposited with $(-100 \mathrm{~V})$, i.e. the plastic deformation (see Fig. 8, a) due to the applied load is more markedly reduced than that of other coatings deposited without the bias voltage. This effect is clearly correlated to the reduction of grain size, increasing the film density, hardness, and elastic recovery $[4,27]$.

\section{Tribological properties}

Pin-on-disk analysis. The friction coefficient values for AISI 8620 steel substrates coated with V-C-N coatings deposited at different bias voltages, were tested against steel balls and presented in Fig. 9, $a$. The friction coefficients curves showed two distinct stages. In the first stage (zone I), the friction coefficient (l) began at a low level (0.18-0.45) in the first contact; this stage can be attributed to the running-in period associated with a kind of contact between the steel ball and the coating, where the formation of wear debris occurs by the cracking of rough- 
ness tips on both counterparts. This stage has a short-time period, then the friction coefficient increases to $0.20-0.50$ followed by a decrease to the friction coefficient of the second stage (zone II). This stage (zone I) is defined as the steady-state friction period and begins after about 20-90 $\mathrm{m}$ of sliding distance (m) [4, 28, 29]. In the zone II, from (pin-on-disk analysis picture), it was possible to observe the distance settling range (steady-state friction period) between 100 and $400 \mathrm{~m}$ for each of the friction curves. In these results, there were not significant changes appreciated in the increase of the friction coefficient. This effect may be associated to overcome the distance of $100 \mathrm{~m}$, the surfaces of the tribological pair between $100 \mathrm{Cr} 6$ steel pin and the $\mathrm{V}-\mathrm{C}-\mathrm{N}$ system was normalized relative to the contact surface which had higher ( $\mathrm{V}-\mathrm{C}-\mathrm{N})$ Young's modulus generating a constant Er and a coefficient of friction almost invariable. Figure $9, b$ shows the friction coefficient as a function of the applied negative bias voltage.
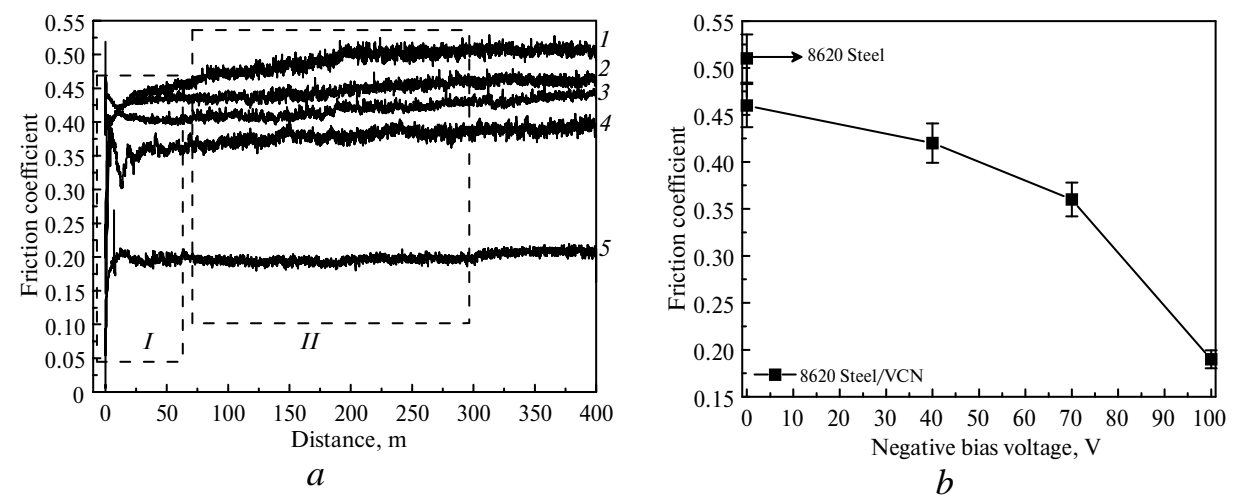

Fig. 9. Tribological results of 8620 steel substrates coated with V-C-N single layers coatings: friction coefficient as a function of a sliding distance (steel (1), 0 (2), -40 (3), -70 (4), -100 (5) $\mathrm{V}(a)$ and friction coefficient as a function of the applied negative bias voltage $(b)$.

Tribological properties of $\mathrm{V}-\mathrm{C}-\mathrm{N}$ carbon nitride coatings are provided in Fig. 10 for comparison in relation to single layer systems. These tribological results showed the reduction of the friction coefficient while the applied negative bias is increased. Thus, the friction coefficient of $\mathrm{V}-\mathrm{C}-\mathrm{N}$ coatings ranged from approximately $0.46-0.19$, being the lowest value reported for the single layers growth at $V=-100 \mathrm{~V}$ (friction coefficient 0.25) [19]. In this regard, the friction coefficient value represented a decrease at approximately $58 \%$ of the friction coefficient with respect to the $\mathrm{V}-\mathrm{C}-\mathrm{N}$ coating deposited at $0 \mathrm{~V}$. The last behavior can be related to the friction mechanical model proposed by Archard [30], which relates the contribution of the contact surface roughness and the elastic-plastic properties of the coating in the following equation:

$$
\mu=\frac{F_{f}}{F_{N}}=C_{k} \frac{R_{(s, a)}}{\sigma t_{(H, E r)}},
$$

where $\mu$ is the friction coefficient, $C_{k}$ is a constant that depends on the parameter of the test, $R_{(s, a)}$ is the coating roughness, and $\sigma t$ is a variable that takes into account the elastic-plastic properties (hardness, $\mathrm{H}$, or elastic modulus, $\mathrm{Er}$ ), obtained by mechanical measures [29]. In agreement with the model presented by Archard, when the surface coating has low roughness and high hardness, the friction coefficient will tend to decrease and will be stable for long sliding distances, specifically if the counterpart of the test is softer than the coating. On the other 
hand, although hardness has long been regarded as a primary material property that defines wear resistance, strong evidences suggest that the elastic modulus can also have an important influence on the wear behavior. In particular, the elastic strain to failure, related to the ratio of hardness $H$ and elastic modulus $E r$, which has been shown by a number of authors to be a more suitable parameter to predict wear resistance than with hardness alone.

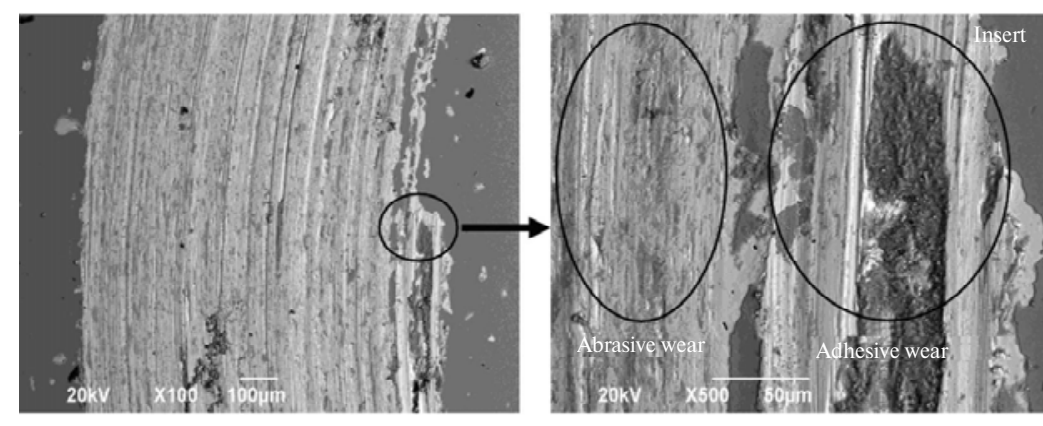

$a$

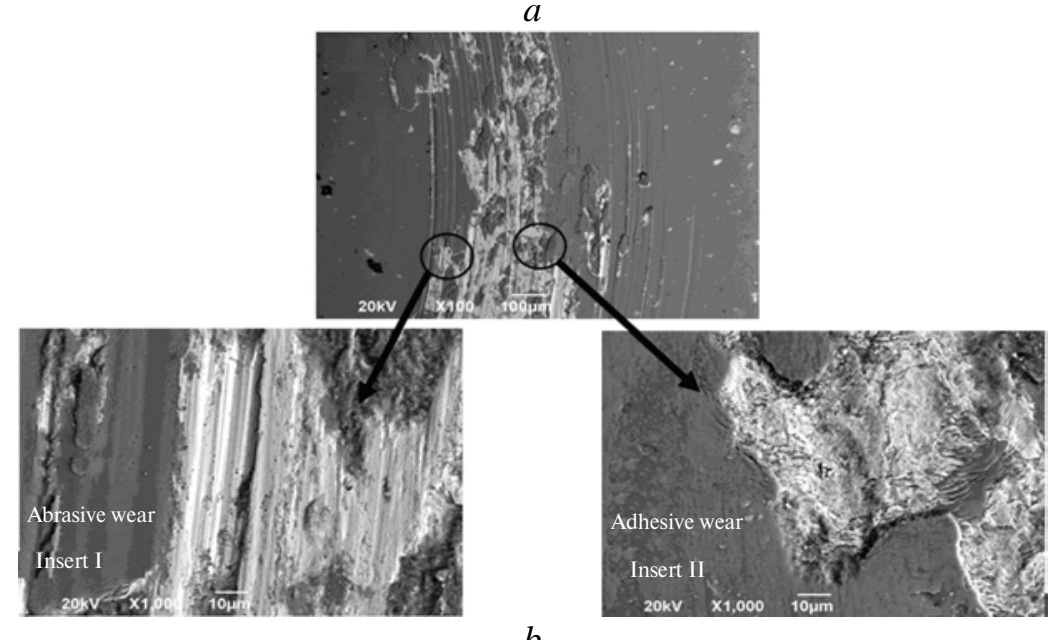

$b$

Fig. 10. SEM micrograph of wear track on V-C-N coatings deposited on AISI 8620 steel: $\mathrm{V}-\mathrm{C}-\mathrm{N}$ coating deposited with negative bias voltages of $0 \mathrm{~V}(a)$, and $\mathrm{V}-\mathrm{C}-\mathrm{N}$ coating deposited with negative bias voltages of $-100 \mathrm{~V}(b)$.

In this research, it is possible to discuss the concept of ternary carbon nitride $(\mathrm{V}-\mathrm{C}-\mathrm{N})$ with relatively high hardness and high elastic modulus, which can exhibit improved toughness and are, therefore, better suited to optimize the wear resistance of "real" industrial substrate materials (i.e., mechanical devices with low moduli). Recent advances in the development of metal-ceramic coatings are summarized and discussed in terms of their relevance to practical applications. Therefore, it is possible to observe that the elastic strain to failure, which is related to $H^{3} / E^{2}$ (see Fig. 9), affects the tribological behavior of $\mathrm{V}-\mathrm{C}-\mathrm{N}$ single layer. That provides superior wear resistance when deposited on the substrate materials for mechanical applications [4, 31]. Consequently, this behavior suggests that improving plastic deformation resistance $\left(H^{3} / E^{2}\right)$ when the negative bias voltage is increased, exerts more wear resistance due to enhanced mechanical properties (see Fig. 9) associated with the changes in the internal stress (previously observed in XRD results), thus, generating a reduction in the friction coefficient (see Fig. 9, $b$ ). 
As can be seen in Fig. 10 (SEM micrographs), it is possible to find different wear mechanisms, such abrasive wear (scuffing), adhesive wear, oxidation, and diffusion. In this sense, the abrasion mechanism is a predominant phenomenon at $\mathrm{V}-\mathrm{C}-\mathrm{N}$ coatings with a low bias voltage (low mechanical and tribological properties, see Figs. 6-9). The value of a negative bias voltage, at which the maximum wear values occur will depend on different factors like the combination of high roughness, small grain size (see Figs. 4, 5 ), and low elastic modulus, among others. Therefore, in this research it was presented the wear surface for V$\mathrm{C}-\mathrm{N}$ coatings deposited with different bias voltages (from 0 to $-100 \mathrm{~V}$ ), showing thus changes in the wear mechanisms when the negative bias voltages were applied and increased respectively (e.g., reduction in scuffing presence on $\mathrm{V}-\mathrm{C}-\mathrm{N}$ deposited with $-100 \mathrm{~V}$ ).

\section{Adherence analysis by using a critical load criterion}

Adhesion behavior. The scratch test was used to characterize the coating adherence strength. The adhesion properties of single-layer coatings can be characterized by the following two terms: $\mathrm{L}_{\mathrm{C} 1}$, the lower critical load, which is defined as the load where cracks first occurred (cohesive failure); and $\mathrm{L}_{\mathrm{C} 2}$, the upper critical load, which is the load where the first delaminating at the edge of the scratch track occurred (adhesive failure) [31]. The values of critical load ( $\mathrm{L}_{\mathrm{C} 1}$ and $\mathrm{L}_{\mathrm{C} 2}$ ) for the different coatings are shown in Fig. 11. The $\mathrm{L}_{\mathrm{C} 1}$ was shown for the different coatings in the range of 8.3-15 $\mathrm{N}$, in which the lowest value was attributed to the hard coatings deposited with the bias voltage of $0 \mathrm{~V}$ and the highest value was attributed to the $\mathrm{V}-\mathrm{C}-\mathrm{N}$ ternary system growth with the negative bias voltage of $-100 \mathrm{~V}$.
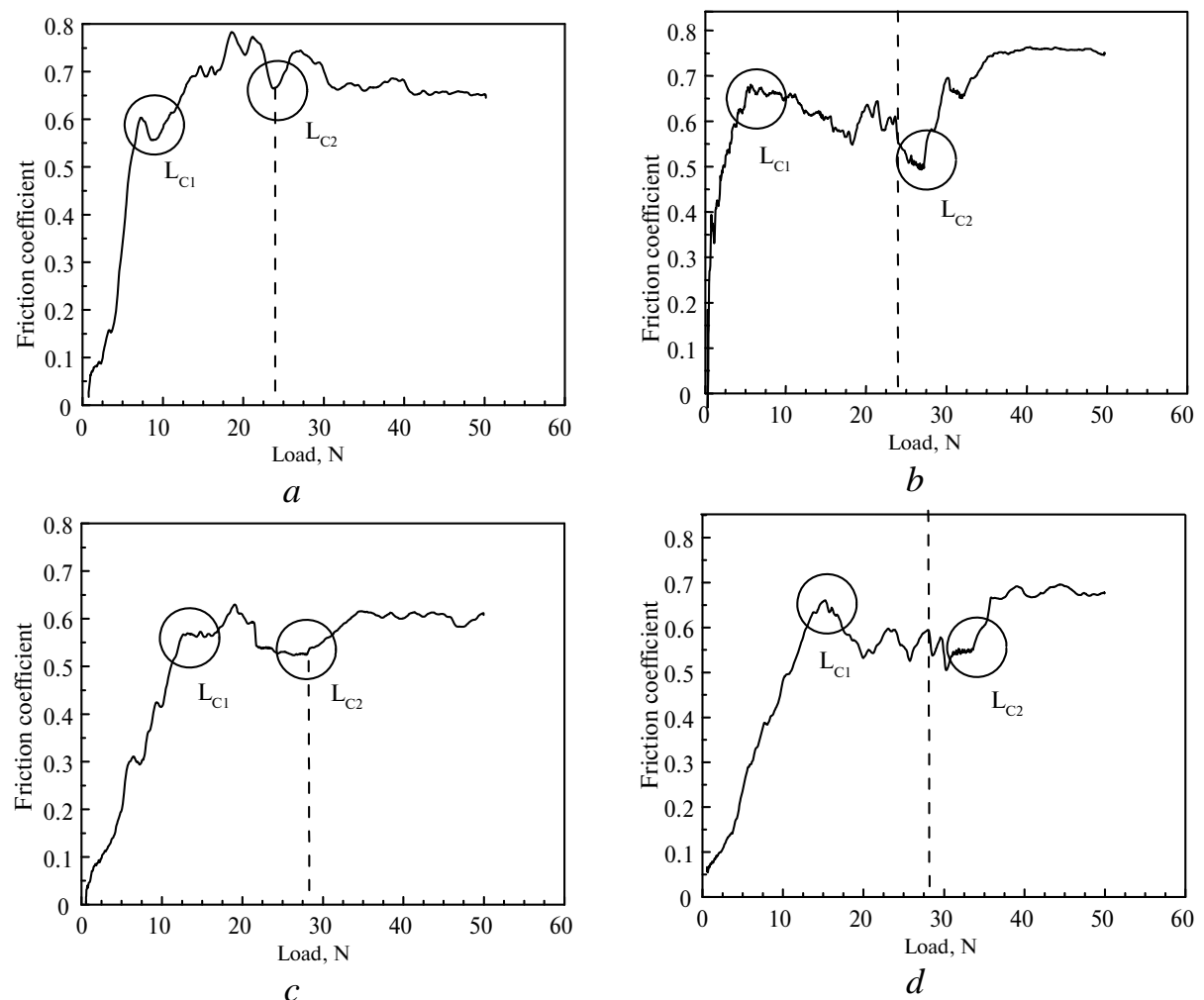

Fig. 11. Tribological results for friction coefficient curves vs. applied load for $\mathrm{V}-\mathrm{C}-\mathrm{N}$ coatings deposited with different applied negative bias voltages, showing thus the adhesion failure $\left(\mathrm{L}_{\mathrm{C} 2}\right)$ : $0(a),-40(b),-70(c),-100(d) \mathrm{V}$. 
The critical loads in adhesive failure $\left(\mathrm{L}_{\mathrm{C} 2}\right)$ values for the different coatings are summarized in Fig. 12. This figure clearly shows that the adhesion properties of metal ceramic coatings increase as a function of the increase in the applied negative bias. Due to the quantitative adhesion measurements between the layers and substrates, this process is complex even for single layer coatings, which is in agreement with some previously published reports [4, 29]. A qualitative characterization is necessary to evaluate the adhesion behavior of $\mathrm{V}-\mathrm{C}-\mathrm{N}$ coatings, as described before in this section, that is, in terms of $\mathrm{L}_{\mathrm{C} 1}$ and $\mathrm{L}_{\mathrm{C} 2}$ critical loads. Therefore, for the purpose of ensuring a fair comparison between the different ternary coatings, it was assumed that the adhesion between the substrate and the single layer remains constant for similar applied negative bias voltage (since the preparation conditions and parameters were the same). Besides, in all cases, it was verified that the parameters of the scratch test for all samples were also the same. According to the latter, it was expected that the response to the applied load and adhesive failure will only depend on the coating properties due to the applied negative bias voltage effect.

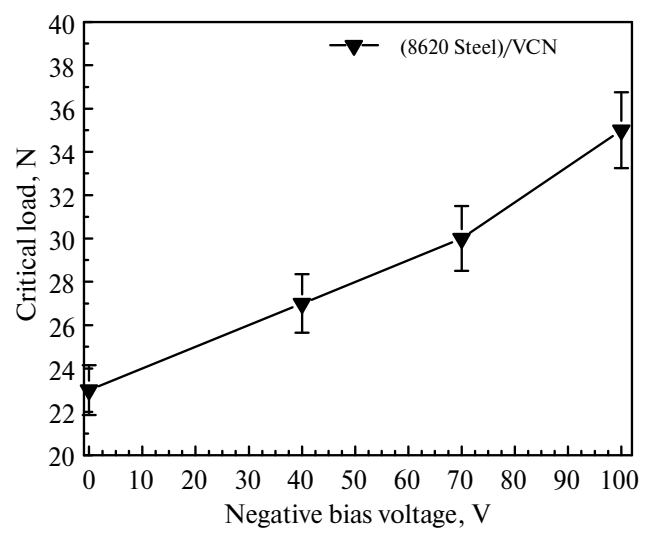

Fig. 12. Correlation of critical loads (adhesive failure) as a function of applied negative bias voltage for all $\mathrm{V}-\mathrm{C}-\mathrm{N}$ coatings.

From Fig. 12, it was possible to analyze that the values of critical load increased when the applied negative bias voltage was increased. Then, this improvement is in part due to the increase in the coating/substrate deformation resistance (see Fig. 8). In this mechanism, the densification and grain size reduction (see Figs. 4, 5) serves as a crack tip deflector that changes the direction of the initial crack when it penetrates deep into the coating, and strengthens the coating performance. Moreover, by decreasing the grain size, the dislocations among the boundaries grain found a major impediment to moving; therefore, those dislocations will require higher critical shear stress to move and spread throughout the coating and allow delaminating the $\mathrm{V}-\mathrm{C}-\mathrm{N}$ coating. This effect means that carbon nitride coatings can fail in a fragile manner [32, 33] because these coatings are homogeneous systems. In consequence, the ternary single layers such as those studied in the current work can enhance the resistance of coatings against crack propagation in relation to the mechanical property evolution presented by the enhanced hardness and elastic modulus (see Fig. 7) with highest elastic recovery ( $R$, \%) (see Fig. 8), preserving the integrity of the coatings under punctual (static) and dynamic loads [34]. It was observed that an increase of $34 \%$ in the $\mathrm{L}_{\mathrm{C} 2}$ for $\mathrm{V}-\mathrm{C}-\mathrm{N}$ coating deposited with the applied negative bias voltage of $-100 \mathrm{~V}$ in relation to the single layer coating growth with the lowest applied negative bias voltage $(0 \mathrm{~V})$. 
Surface tribological analysis. Scanning electron microscopy images showing the different behaviors of $\mathrm{V}-\mathrm{C}-\mathrm{N}$ coatings deposited with different negative bias voltages, after scratch tests are shown in Figs. 13, $a$ and $b$. These images revealed that at the beginning of the scratch, pronounced deformation appeared due to the substrate plastic deformation and a coating debris removal, associated with the adhesive layer/substrate failure mechanism sideward lateral flanking [35]. Thus, SEM images confirm the scratch test results observed in Fig. 13. Figure 13, $a$ shows a premature adhesion failure due to the accumulation of stress at the scratch edges to the ternary coating growth with the lowest bias voltage $(0 \mathrm{~V})$ in relation to $\mathrm{V}-\mathrm{C}-\mathrm{N}$ coating deposited with the highest applied negative bias voltage (see Fig. $13, d)$.

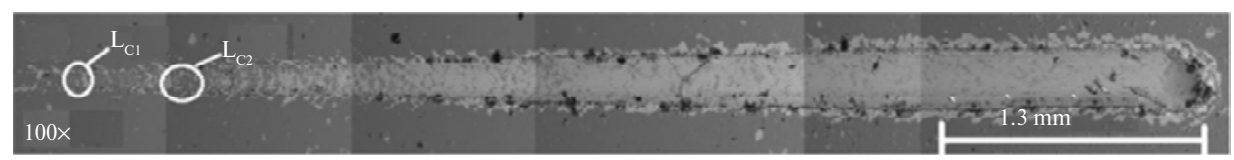

$a$

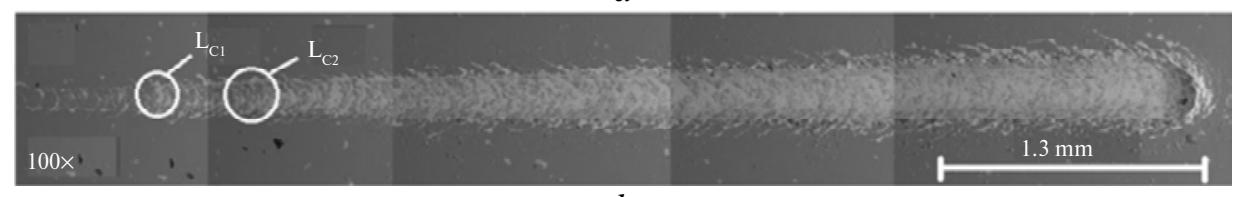

$b$

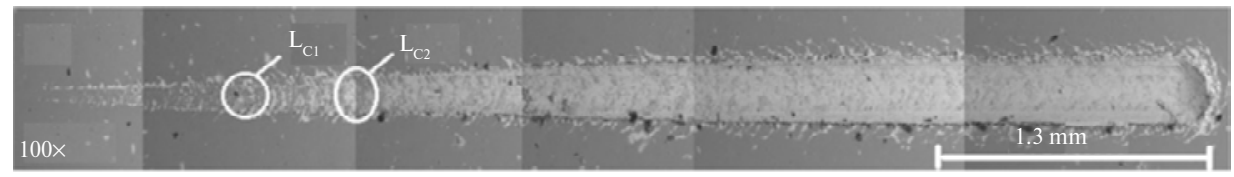

c

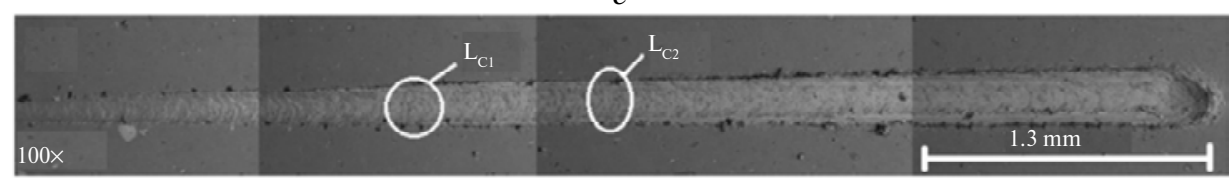

$d$

Fig. 13. SEM micrographs of scratch tracks: $0(a),-40(b),-70(c),-100(d) \mathrm{V}$ deposited onto industrial AISI 8620 steel.

Further away from scratch, conformal cracking of the layer associated with adhesive failure $\left(\mathrm{L}_{\mathrm{C} 2}\right)$ appears in a single layer coating with a relative low bias voltage. But unlike the last discussion, the coatings deposited with $-100 \mathrm{~V}$ presented "Recovery Spallation" type wear mechanisms (see Fig. 13, d). These series of ternary coatings showed a failure behavior type "Buckling Cracks" that is characteristic of protective systems where the substrate is ductile and hard coatings have good adhesion between them, these systems generate compressive stress that are characteristic of cracks buckling failure mode [4, 31].

It was found that the highest values of hardness and elastic modulus, 29 and $261 \mathrm{GPa}$, respectively, were observed for V-C-N coating growth with $(-100 \mathrm{~V})$ bias voltage. The enhancement in the hardness value of the metal ceramic coating stack was attributed to high density that blocking the micro-crack movements across the boundaries grain due to the reduction of the pores occurrences; together with the Hall-Petch models, which gives a good overall picture of the hardness enhancements.

Furthermore, the tribological performance for $\mathrm{V}-\mathrm{C}-\mathrm{N}$ coating with critical loads in adhesive failure of $35 \mathrm{~N}$ and friction coefficient of 0.19 were observed for 
the ternary metal ceramic material deposited with a bias voltage of $-100 \mathrm{~V}$. From the SEM micrographs, it was determined that for the single layer coatings different types of adhesive layer/substrate failures appear under strong plastic deformation conditions, which is important for the preparation of wear resistant cutting and forming tools and mechanical devices used in industrial applications.

\section{CONCLUSIONS}

The applied r.f. negative bias voltage in the ternary $\mathrm{V}-\mathrm{C}-\mathrm{N}$ coatings was varied from 0 to $-100 \mathrm{~V}$ generating a slightly shift of the peak positions to lower angles, due to the increase in the tensile residual stress at higher voltages. The r.f. bias application induces important formation of crystallographic phases with similar intensity such as fcc (111) and (200).

The chemical, morphological, and mechanical characteristics and properties are strongly related to the applied negative bias voltage, therefore, the evolution in the dynamical surface and physical properties have been found when the bias voltage was applied on V-C-N material around $-100 \mathrm{~V}$ (hardness - $30 \mathrm{GPa}$ and elastic modulus - $260 \mathrm{GPa}$ ).

The lowest critical load in the coatings was found when a r.f. negative bias of $-100 \mathrm{~V}$ was applied, observing thus an enhancement of the tribological properties by reduction of the friction coefficient in $60 \%$ for $\mathrm{V}-\mathrm{C}-\mathrm{N}$ coatings when both coatings were compared with the same deposited $0 \mathrm{~V}$, therefore, a high critical load for adhesive failure was obtained in coatings due to two factors: growth with the highest negative bias voltage, which produce the increase of the density, and therefore, improve the mechanical properties (hardness and elastic modulus) which can be used in manufacture industry (e.g. tools for High Efficiency Machining).

\section{ACKNOWLEDGEMENTS}

This research was supported by Universidad Militar Nueva Granada, contract number ING-1775-2015, Universidad del Quindío and the CIC biomaGUNE, Platform Manager - Surface Analysis and Fabrication, Spain.

Метою роботи було визначення механічної та трибологічної поведінки V-C-N-nокриттів, осаджених на сталеві (AISI 8620) підкладки, для використання як захисні матеріали. Покриття осаджували на кремнісві (100) і сталеві підкладки магнетронним напиленням при зміні напруги зміщення. Дослідження за допомогою рентгенівської дифракиії показали, щчо $V-C-N$-покриття мали кристалографічну орієнтацію (111) для ГЦК V-C-N-структури, утвореної VC (111) $i$ VN (111) фазами, $i$ (200) для ГЦК V-C-N-структури, утвореної VC (200) $i$ VN (200) фазами. Рентгенівська фотоелектронна спектроскопія була використана для визначення хімічного складу металевих вуглець-нітридних матеріалів. Для визначення зернистості і шорсткості при зміні параметрів осадження була використана атомно-силова мікроскопія. 3 використанням наноіндентування, методу “диск-стрижень” $i$ кривих склерометричних випробувань оиінювали твердість, тертя $і$ критичне навантаження матеріалу поверхні $\mathrm{V}-\mathrm{C}-\mathrm{N}$. Pacтрову електронну мікроскопію використовували для аналізу змін морфології поверхонь. Дослідження механічних та трибологічних характеристик системи VCN/cmаль[8620] як функиії напруги зсуву показали збільшення твердості на 58 \% $і$ зменшення коефіцієнта тертя на $39 \%$, звідки випливає, щео $\mathrm{V}-\mathrm{C}-\mathrm{N}$-покриття можуть бути перспективними для застосування в промисловості.

Ключові слова: поверхня, зростання кристала, фізичне осадження 3 парової фази, механічне випробування, трибологія $i$ знос.

Целью работы было определение механического и трибологического поведения V-C-N-покрытий, осажденных на стальные (AISI 8620) подложки, для использования как защитные материалы. Покрытия осаждали на кремниевые (100) и стальные 
подложки магнетронным напылением при изменении напряжения смещуения. Исследования с помощуью рентгеновской дифракции показали, что $V-C-N$-покрытия имели кристаллографическую ориентацию (111) для ГЦК V-C-N-cтруктуры, образованной VC (111) и VN (111) фазами, и (200) для ГЦК V-C-N-cтруктуры, образованной VC (200) u VN (200) фазами. Рентгеновская фотоэлектронная спектроскопия была использована для определения химического состава металличских углерод-нитридных материалов. Для определения зернистости и шероховатости при изменении параметров осаждения была использована атомно-силовая микроскопия. С использованием наноиндентирования, метода “стержень-диск” и кривых склерометрических испытаний оченивали твердость, трение и критическую нагрузку материала поверхности V-C-N. Растровую электронную микроскопию использовали для анализа изменений морфологии поверхностей. Исследования механических и трибологических характеристик системь VCN/cталь[8620] как функции напряжения смещуения показали увеличение твердости на 58 \% и уменьшение коэффициента трения на 39 \%, откуда следует, что V-C-N-покрытия могут быть перспективными для применения в промыцленности.

Ключевые слова: поверхность, рост кристалла, физическое осаждение из паровой фазы, механическое испьтание, трибология и износ.

1. Silva E., Rebelo de Figueiredo M., Franz R. et al. Structure-property relations in ZrCN coatings for tribological applications // Surf. Coat. Tech. - 2010. - 205. - P. 2134-2141.

2. Rodziňák D., Čerňan J., Hvizdoš P. Effect of TiCN coating on tribological properties of Astaloy CrL sintered steel // J. Manuf. Indust. Eng. - 2013. - N 12. - P. 20-24.

3. Kohjiro S., Kiryu S., Shoj A. Surface resistance of epitaxial and polycrystalline NbCN films in submillimeter wave region // Transact. Appl. Supercon. - 1993. - N 3. - P. 1765-1767.

4. Cabrera G., Caicedo J. C., Amaya C. et al. Enhancement of mechanical and tribological properties in AISI D3 steel substrates by using a non-isostructural CrN/AIN multilayer coating // Mater. Chem. Phys. - 2011. - 125. - P. 576-586.

5. Kurt B., Onder E., Carboga C., Demirel B. Characterization and kinetics of VC coatings on AISI D3 steel performed by thermo-reactive diffusion technique // Pract. Metallogr. - 2014. 51. - P. 42-44.

6. Farges G., Beauprez E., Degout D. Preparation and characterization of VN films deposited by reactive triode magnetron sputtering // Surf. Coat. Tech. - 1992. - 55. - P. 115-120.

7. Caicedo J. C., Zambrano G., Aperador W. et al. Mechanical and electrochemical characterization of vanadium nitride (VN) thin films // Appl. Surf. Sci. - 2011. - 258. - P. 312- 320.

8. Grigore E., Ruset C., Luculescu C. The structure and properties of VN-VCN-VC coatings deposited by a high energy ion assisted magnetron sputtering method // Surf. Coat. Tech. 2011. - 205. - P. S29-S32.

9. Mitterer C., Fateh N., Munnik F. Microstructure-property relations of reactively magnetron sputtered $\mathrm{VC}_{\mathrm{x}} \mathrm{N}_{\mathrm{y}}$ films // Ibid. - 2011. - 205, N 13-14. - P. 3805-3809.

10. Heo S. Y., Shin J. H., Kim D.-I. et al. Microstructure and mechanical properties of Cr-V-C-N films // Surf. Eng. - 2015. - 31. - P. 513-518

11. Fateh N., Fontalvo G. A., Gassner G., Mitterer C. Influence of high-temperature oxide formation on the tribological bahaviour of TiN and VN coatings // Wear. - 2007. - 262. P. 1152-1158.

12. Hanumantha P. J., Datta M. K., Kadakia K. S. et al. A simple low temperature synthesis of nanostructured vanadium nitride for supercapacitor applications // J. Electrochem. Soc. 2013. - 160, N 11. - P. 2195-2206.

13. Laurent F., Michel P., Feurer R. et al. New organometallic route to vanadium carbonitride thin films // J. Mater. Chem. - 1993. - 3, N 6. - P. 659-663.

14. Gonçalves G., Vila M., Bdikin I. et al. Breakdown into nanoscale of graphene oxide: Confined hot spot atomic reduction and fragmentation // Nature Sci. Rep. - 2014. - N 4, art. 6735.

15. Junbo L. I., Xiwen L., Cancan C. et al. Silica-gel supported V complexes: preparation, characterization and catalytic oxidative desulfurization // Chinese J. Chem. Eng. - 2013. - 21, N 8. - P. 860-866.

16. Bacal M., Perrière J., Tanguy M. et al. Study of carbon nitride films deposited using a Halltype ion source // J. Phys. D: Appl. Phys. - 2000. - 33, art. 2373.

17. Franz R., Neidhard J., Sartory B. et al. Micro- and bonding structure of arc-evaporated AlCrVN hard coatings // Thin Solid Films. - 2008. - 516. - P. 6151-6157. 
18. Grigore E., Ruset C., Luculescu C. The structure and properties of VN-VCN-VC coatings deposited by a high energy ion assisted magnetron sputtering method // Surf. Coat. Tech. 2011. - 205. - P. 29-32.

19. Oliver W. C., Pharr G. M. An improved technique for determining hardness and elastic modulus using load and displacement sensing indentation experiments // J. Mater. Res. 1992. - 7, N 6. - P. 1564-1583.

20. Caicedo J. C., Yate L., Montes J. Improving the physicochemical surface properties on AISI D3 steel coated with Ti-W-N // Ibid. - 2011. - 205. - P. 2947-2953.

21. Wiora M., Brühne K., Flöter A. et al. Grain size dependent mechanical properties of nanocrystalline diamond films grown by hot-filament CVD // Diamond Relat. Mater. - 2009. - 18. - P. 927-930.

22. Hiroshi G., Masahide G., Shoichi E. et al. Scratch test of TiCN thin films with different preferred orientation // Mater. Sci. Forum. - 2006. - 524. - P. 729-734.

23. Gupta S., Glocker D., Romach M. Nanoindentation and X-ray diffraction study of sputtered TiCN coatings // Microsc. Microanal. - 2004. - 10. - P. 602-603.

24. Yashar P. C., Sproul W. D. Nanometer scale multilayered hard coatings // Vacuum. - 1999. 55. - P. 179-190.

25. Caicedo J. C., Aperador W., Caicedo H. H. Physical and tribological diagnostic of Ti(Carbon Nitrides) and Ti-Nb-(Carbon Nitrides) coatings // J. Mech. Sci. Tech. - 2014. - 28, N 2. - P. 489-497.

26. Kim Gwang S., Lee Sang Y., Hahn Jun H. Synthesis of CrN/AlN superlattice coatings using closed-field unbalanced magnetron sputtering process // Surf. Coat. Tech. - 2003. - 171. P. 91-95.

27. Hajek V., Rusnak K., Vlcek J. et al. Tribological study of $\mathrm{CN} x$ films prepared by reactive d.c. magnetron sputtering // Wear. - 1997. - 213. - P. 80.

28. Martínez E., Romero J., Lousa A., Esteve J. Nanoindentation stress-strain curves as a method for thin-film complete mechanical characterization: application to nanometric $\mathrm{CrN} / \mathrm{Cr}$ multilayer coatings // Appl. Phys. A. - 2003. - 77. - P. 419-426.

29. Holleck H., Lahres M., Woll P. Multilayer coatings - influence of fabrication parameters on constitution and properties // Surf. Coat. Tech. - 1990. - 41. - P. 179-190.

30. Archard J. F. Contact and rubbing of flat surfaces // J. Appl. Phys. - 1953. - 24, N 8. P. 981.

31. Leyland A., Matthews A. On the significance of the H/E ratio in wear control: a nanocomposite coating approach to optimised tribological behaviour // Wear. - 2000. - 246. - P. 1-11.

32. Veprek S., Reiprich S. A. Concept for the design of novel superhard coatings // Thin Solid Films. - 1995. - 268. - P. 64-71.

33. Podgornik B., Hogmark S., Sandberg O., Leskovsek V. Wear resistance and anti-sticking properties of duplex treated forming tool steel // Wear. - 2003. - 254. - P. 1113-1121.

34. Holmberg K., Ronkainen H., Matthews A. Tribology of thin coatings // Ceram. Int. - 2000. 26. - P. 787-795.

Received 09.11.15 